\title{
Cause Traced to Transport/Storage
}

National Cancer Institute

\section{Source}

National Cancer Institute. Cause Traced to Transport/Storage. NCI Thesaurus. Code C139474.

Problems traced to the inappropriate transport or storage of the device. 